\title{
Economic Valuation of Urban Trees: Ribnjak Park Case Study, Zagreb
}

\author{
Karlo Beljan ${ }^{1 \Xi}$, Stjepan Posavec ${ }^{1}$, Krešimir Jerčić ${ }^{2}$ \\ ${ }^{1}$ University of Zagreb, Faculty of Forestry, Department of Forest Inventory and Management, \\ Svetošimunska 25, HR-10000 Zagreb, Croatia \\ 2 Muć Donji 75, HR-21203 Donji Muć, Croatia \\ $\varangle$ Corresponding author: e-mail: kbeljan@sumfak.hr
}

Citation:

BELAN K, POSAVEC S, JERČIĆ K 2015 Economic Valuation of Urban Trees: Ribnjak Park Case Study, Zagreb. Southeast Eur for 6 (1): 119-127. DOI: http://dx.doi.org/10.15177/seefor.15-08

Received: 15 Oct 2014;

Accepted: 18 Mar 2015;

Published online: 20 Apr 2015

\section{Abstract}

Background and Purpose: Population growth, urbanisation and technological development are creating a growing need for urban forests and parks, which are becoming green oases for recreation and relaxation. Apart from the sociological and economic components, urban forest valuation is presented through tourism, the market value of main and secondary forest products, and the growing value of real estate in the vicinity of green areas. Environmental economics explores the optimal ratio between the costs and the benefits received from the investment in the environment. The aim of this research is monetary valuation of urban trees.

Materials and Methods: A Danish model for tree value determination was applied in Ribnjak Park as a case study. The model is based on tree growing costs and the present value. It is limited by the subjective aesthetic tree value estimation, but it is used in Europe because of its practicality. Individual tree value estimation is used because of the tree damage from vehicles or new residential buildings. The method is suitable for individual trees or groups of trees, but it is not appropriate for forest stands. Twenty random selected trees from nine different tree species have been analysed in the park. Diameter at breast height, tree height, expected age, aesthetic value and location were recorded for each tree. Furthermore, ecological, social and health tree values were taken into account separately with the calculation of points.

Results: According to the evaluation, the average monetary value of one tree in Ribnjak Park is 542 EUR. The average diameter at breast height is $57.86 \mathrm{~cm}$ with the average age of 96.14 years. Plane trees have the highest value in comparison to other sampled species.

Conclusions: Tree values vary depending on age, dimension or aesthetic values. The disadvantage of this method is in the estimation of very old tree value and in high involvement of personal estimation, which creates an opportunity for future development of the model and for its modification. The calculation of urban forest values is a complex process because of its impossibility to do a market evaluation of all of the benefits that could be considered as public wealth.

Keywords: urban tree, urban forest, evaluation, compensation price 


\section{INTRODUCTION}

The importance of trees and forests in industrial cities has always been related to health, recreation and aesthetic benefits. Forests and forest lands are especially important from a local, social and cultural point of view. Individual trees and other forest complexes have not been sufficiently recognised in the planning of the urban environment development. The purpose of the valuation is to provide information necessary for decision making because available resources are scarce and it is important to manage those resources in a way that contributes to human well [1]. There is a need for research on the role of urban forests and trees in improving the environment and on their relation to social functions, such as mental and physical benefits $[1,2]$.

One of the most common purposes of urban forests and parks is to provide an opportunity for recreational activities. Walking is the most common type of recreation with a $81 \%$ share in Finland [3] and 74\% in the Netherlands [4]. The average visit rate in Italy is only four times a year, but one visit lasts almost four hours. The average visit rate is much higher in Finland, with 72-110 visits a year, but the visits last usually from 30 minutes to one hour [5]. Other common activities include cycling, jogging, picnics or picking berries and mushrooms. Forests closer to big cities are the most frequented ones. The Dutch State Forest Service has estimated for city forests approximately 1000 visitors per hectare a year. The majority of visitors are aware of the importance of ecological management over the past ten years [6].

In the survey on the City of Salo (Finland) half of the participants pointed out remoteness as the main reason why urban recreational areas are underused [7]. Stress reduction, measured through the muscle tension, blood pressure and the brain's electric activity can be found in the human body within few minutes of being exposed to a green area [8]. The key factor for safety in forests is visibility, which presupposes the active management of the ground floor, giving the impression of a controlled area [6].
Social interaction and cohesion is another way of linking nature and health. While European research on this subject matter is still scarce, several researches conducted in Chicago (USA) show that green surfaces, especially trees, contribute to social interaction between neighbours [9] since they reduce the sense of social isolation, one of the factors which cause depression.

The traditional methods for evaluating the forests' value include the opportunity costs, the estimated maintenance costs and the forest production value. These methods are based on assessing the market value of forest goods, so their use in city forests is limited [10]. The methods used in evaluating the benefits (services) of forests without including the market value are: Contingent Valuation Method (CVM), Hedonic Price Method (HPM) and Travel Cost Method (TCM). Additional methods for evaluating the benefits of city forests include the tree value evaluation and the ecological benefit evaluation $[4,10]$. Putting value on urban forest benefits helps the decision makers to make informed decisions about urban forests, ideally based on cost- benefit analysis. This is in line with the concept of usable science, where scientific results can serve as valuable information to the political actors in the process of deliberation [11]. The objective of this research is to determine monetary values of urban trees in Ribnjak Park using Danish method.

\section{MATERIALS AND METHODS}

\section{Research Object}

Ribnjak Park is located in the centre of Zagreb and stretches along the eastern walls of Kaptol. It was named after the bishop's fishponds that existed there until the $19^{\text {th }}$ century. Afterwards the entire area was transformed into an English type park with waterfalls, exotic plants, a decorative statue "Stid" (eng. shame) by Antun Augustinčić and a monument to the Croatian poet Ivan Goran Kovačić. The present park has the area of $40000 \mathrm{~m}^{2}$; it has a 30 year old Taxus baccata L., an old specimen of Cedrus atlantica 
Manetti, many magnolias and a liquidambar. The park was fully open to public in middle 1940 and it was extended northward to include the former canonical gardens. Landscape architecture plans, which were made in 1946, are still actual today and they include some modern Croatian sculptors [12].

Ribnjak Park, as a green area in the old town, is surrounded by a frequent traffic road with tram lines and thousands of cars per day. During the day, there is an active children playground in the park and during the night it is a local club circuit. In the meantime there are tourists visiting the park and citizens walking their pets. It is clear that such a frequently used green area needs improvements in services and management.

\section{Research Method}

The benefits of trees and forests in the city are: i) social (recreation), ii) aesthetic and architectural, iii) climate and physical, iv) economic (the market value of forest products such as timber, mushrooms and berries, increased property value, tourism), and v) ecological. The selected method for determining the price of trees presupposes the value of wood based on the following factors: size (diameter at breast height - DBH, tree height), expected age, aesthetics, location, form and other special features (Table 1).

The method is based on the depletion principle; it is spread widely and used in Europe on account of its practicality [2]. It is necessary to determine the price of individual trees to be able to be compensated in case of damages caused by cars or construction. Notwithstanding, this is based on subjective estimation to a certain extent. It is usually used for individual trees or groups of trees, and it is not appropriate for woody areas. Moreover, it does not directly calculate the values offered by the trees (shade, pollution absorption).

TABLE 1. Example of determining the price of trees using the Danish formula [17]

VAT 03 - Tree evaluation - Danish model developed in 2003

Locality: Zagreb, Ribnjak Park

Species:Oak

Date: May $12^{\text {th }} 2014$

Registration No: 17
Pn - price of new tree

$\mathrm{Cn}$ - new tree circumference

$\mathrm{Cd}$ - damaged tree circumference

$\mathrm{E}$ - setting up costs

a- real age (years)

b- expected age (years)

Average with two decimals

Result in 100 of monetary units

If $a<b / 2$, than $A=1$

\begin{tabular}{lcll}
\hline Basic value $(\mathrm{B})=\mathrm{E}+(\mathrm{Pn} / \mathrm{Cn}) *(\mathrm{Cd}-\mathrm{Cn})$ & $\mathrm{B}=629.53$ & \\
\hline Health $(\mathrm{H})$ & Rating $(0-5,5$ max. $)$ & Location $(\mathrm{L})$ & Rating $(0-5,5$ max. $)$ \\
Roots & 5 & Adaptation & 3 \\
Trunk & 4 & Architecture & 3.5 \\
Limbs & 1 & Aesthetics & 4 \\
Smaller branches & 3 & Visibility & 3.5 \\
Twigs, leaves, buds & 4 & Surroundings & 4 \\
Total / 25 & $\mathrm{H}=0.68$ & Total / 12.5 & $\mathrm{L}=1.44$ \\
\hline
\end{tabular}

Age $(A)=\sqrt{\frac{(b-a) \times 2}{b}} \quad A=0.87$

Tree value $=B * H * L * A$ 
The evaluation of the trees' ecological benefits tries to determine how much trees influence the city climate (for example, in terms of shade, evapotranspiration and air circulation changes). These benefits were valuated as an alternative cost of the environment control, and they include the people's willingness to pay for air pollution control or for noise reduction. A concrete example would be energy saving for heating and cooling $[13,14]$. In areas with relatively dense woods it is possible to improve the quality of air by $5-10 \%$ in a limited area $[15,16]$. In 1991, researchers in Chicago determined that the value of the removed air pollution totalled \$1 million. The trees' potential for reducing energy consumption for residential cooling and heating was also researched. The tree coverage of $10 \%$ (roughly three trees per building) decreases energy consumption by $5-10 \%$. Even though this approach is suitable for evaluating all green surfaces, many countries still lack information on the influence of trees on the city climate.

The values of individual trees were calculated based on the formula developed by Danish professor Thomas B. Randrup [17]. According to Randrup et al. [17], the model has been developed to be used under four different circumstances: (i) a tree is damaged to a degree to which the tree will have to be felled, (ii) an existing tree needs to be protected during a construction period, and a penalty value is calculated in order to prevent possible damage, (iii) one or several trees need economic valuation due to expropriation; (iv) a tree is damaged to an extent where it loses value but does not need to be removed. In this research randomly selected samples of 20 trees from all park areas were chosen and the first approach (i) was used. According to this method, the value of trees was determined based on the following indicators: size, expected age, aesthetics, location, shape and other special features. The method does not take into consideration the influence the trees have on the climate. The value of trees was obtained from several parameters: basic values, location coefficient, health and age. The basic value is the initial parameter expressing the value of $1 \mathrm{~cm}$ of the tree's circumference; it is multiplied with grades that either decrease or increase the value. The estimated parameters of location and health are in correlation and could significantly change the estimated economic value. Real tree age could be measured on site but expected tree age is a rough estimation of biological tree parameters. The parameters like Roots, Adaptation, Trunk, Architecture, Limbs, Aesthetics, Smaller branches, Visibility, Twigs, Leaves, Buds and Surroundings are ranked according to the scale from 1 to 5 . It means that the best quality is attributed with grade 5 . This process could be very subjective and it is a weak part of the methodology.

\section{RESULTS}

According to the selected methodology, the basic physic and aesthetic characteristics of the trees were measured or estimated (Table 2). Some variables were measured, like diameter at breast height (DBH) and tree height, while others were estimated. Those variables depend on researcher's judgment and have significant influence on the tree economic value.

In the calculation of the prices, the circumference of the new seedling for all species totals $19 \mathrm{~cm}$, and the cost of setting up all new seedlings is 132.44 EUR. The wholesale price of the new seedling is based on the price list of Zagrebački Holding d.o.o., Zrinjevac Affiliate (Table 3).

According to the evaluation of trees in Ribnjak Park, the average monetary value of one tree is 542 EUR. The average tree diameter at breast height is $57.86 \mathrm{~cm}$ with the average age of 96.14 years (Table 3 ). According to the used formula (Tree value $=B \cdot H \cdot L \cdot A)$, the total value of 11 measured trees is 81914.01 HRK (10849.53 EUR).

Plane trees have the highest monetary value in comparison to all other species which have been sampled in this research. Spruce trees have the lowest monetary value (Figure 1).

The economic value calculated in this research represents the utility and the aesthetic value as one value. In urban forests and parks the share of aesthetic value has the highest share in the total economic value (TEV). 
TABLE 2. Dimensions of trees and the aesthetic features assessment

\begin{tabular}{|c|c|c|c|c|c|c|c|c|c|c|c|c|}
\hline \multirow{2}{*}{ Species } & \multirow{2}{*}{$\begin{array}{l}\text { Circumference } \\
(\mathrm{cm})\end{array}$} & \multirow{2}{*}{$\begin{array}{l}\text { Height } \\
\text { (m) }\end{array}$} & \multicolumn{5}{|c|}{ Health condition } & \multicolumn{5}{|c|}{ Location attractiveness } \\
\hline & & & Root & Trunk & Limbs & $\begin{array}{c}\text { Small } \\
\text { braches }\end{array}$ & Leaves & $\begin{array}{l}\text { Adapt- } \\
\text { ation }\end{array}$ & $\begin{array}{l}\text { Archite- } \\
\text { cture }\end{array}$ & $\begin{array}{l}\text { Aeste- } \\
\text { thics }\end{array}$ & $\begin{array}{l}\text { Visibi- } \\
\text { lity }\end{array}$ & $\begin{array}{l}\text { Enviro- } \\
\text { nment }\end{array}$ \\
\hline $\begin{array}{l}\text { Horse } \\
\text { chestnut }\end{array}$ & 183 & 20.4 & 4 & 2 & 3 & 3 & 3 & 3 & 3.5 & 4 & 3.5 & 4 \\
\hline $\begin{array}{l}\text { Northern } \\
\text { red oak }\end{array}$ & 255 & 24.3 & 3 & 5 & 4 & 3 & 5 & 3 & 3.5 & 4 & 3.5 & 4 \\
\hline Plane tree & 300 & 23.5 & 5 & 2 & 3 & 4 & 5 & 3 & 3.5 & 4 & 3.5 & 4 \\
\hline $\begin{array}{l}\text { Large- } \\
\text { leaved } \\
\text { linden }\end{array}$ & 160 & 20.4 & 4 & 3 & 3 & 4 & 4 & 3 & 3.5 & 4 & 3.5 & 4 \\
\hline Ash & 131 & 23 & 3 & 3 & 4 & 3 & 4 & 3 & 3.5 & 4 & 3.5 & 4 \\
\hline Ash & 153 & 31.6 & 3 & 5 & 4 & 3 & 3 & 3 & 3.5 & 4 & 3.5 & 4 \\
\hline Ash & 165 & 27.2 & 3 & 4 & 3 & 2 & 3 & 3 & 3.5 & 4 & 3.5 & 4 \\
\hline Ash & 122 & 21.4 & 4 & 3 & 4 & 2 & 2 & 3 & 3.5 & 4 & 3.5 & 4 \\
\hline Maple & 105 & 19.9 & 3 & 4 & 5 & 3 & 4 & 3 & 3.5 & 4 & 3.5 & 4 \\
\hline Beech & 200 & 21.4 & 4 & 2 & 3 & 4 & 5 & 3 & 3.5 & 4 & 3.5 & 4 \\
\hline Ash & 230 & 26.8 & 3 & 5 & 4 & 3 & 4 & 3 & 3.5 & 4 & 3.5 & 4 \\
\hline Ash & 160 & 20.5 & 4 & 3 & 4 & 3 & 3 & 3 & 3.5 & 4 & 3.5 & 4 \\
\hline Ash & 145 & 16.1 & 5 & 4 & 4 & 3 & 3 & 3 & 3.5 & 4 & 3.5 & 4 \\
\hline Ash & 164 & 19.8 & 3 & 3 & 3 & 3 & 2 & 3 & 3.5 & 4 & 3.5 & 4 \\
\hline Ash & 190 & 25.2 & 3 & 5 & 4 & 3 & 3 & 3 & 3.5 & 4 & 3.5 & 4 \\
\hline Spruce & 125 & 22.3 & 4 & 4 & 2 & 3 & 5 & 3 & 3.5 & 4 & 3.5 & 4 \\
\hline Oak & 233 & 24.1 & 5 & 4 & 1 & 3 & 4 & 3 & 3.5 & 4 & 3.5 & 4 \\
\hline Ash & 248 & 36 & 3 & 5 & 4 & 4 & 4 & 3 & 3.5 & 4 & 3.5 & 4 \\
\hline Ash & 180 & 23 & 3 & 5 & 4 & 3 & 5 & 3 & 3.5 & 4 & 3.5 & 4 \\
\hline Ash & 185 & 24 & 4 & 5 & 4 & 4 & 5 & 3 & 3.5 & 4 & 3.5 & 4 \\
\hline
\end{tabular}

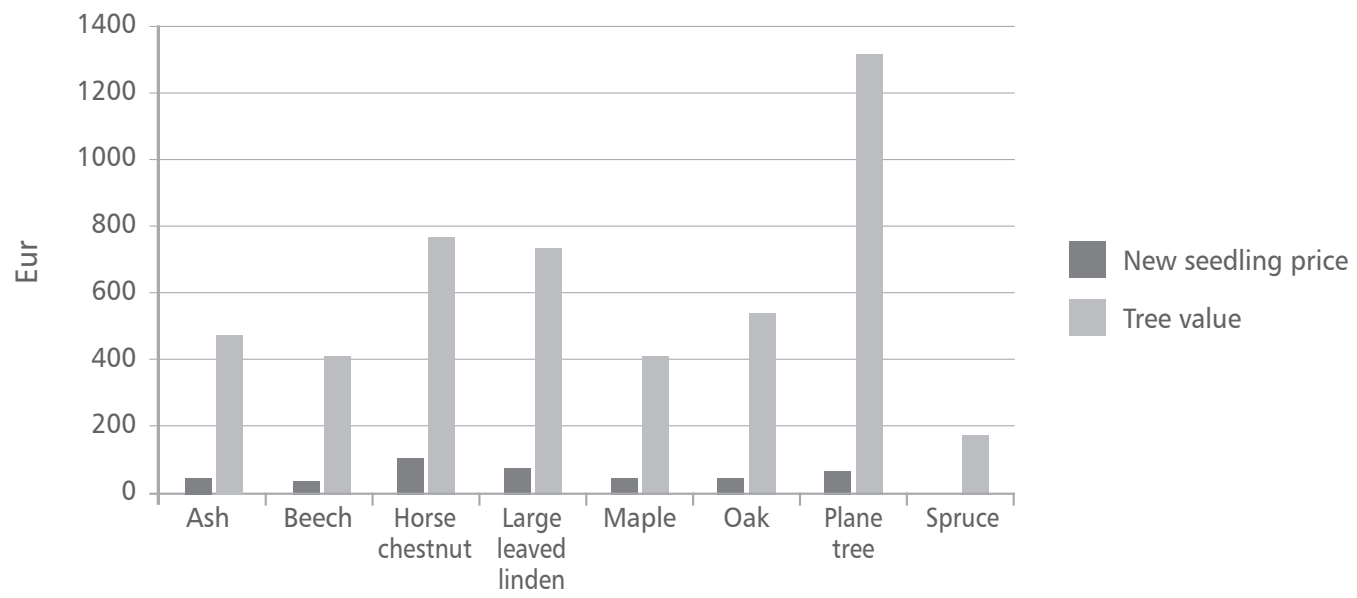

FIGURE 1. The comparison of average thee prices 
TABLE 3. Economic value results

\begin{tabular}{|c|c|c|c|c|c|c|c|c|c|}
\hline \multirow[b]{2}{*}{ Species } & \multirow{2}{*}{$\begin{array}{l}\text { Diameter } \\
\quad(\mathrm{cm})\end{array}$} & \multirow{2}{*}{ 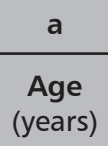 } & \multirow{2}{*}{$\begin{array}{c}\text { b } \\
\text { Expected } \\
\text { age (years) }\end{array}$} & \multirow[b]{2}{*}{ A } & \multirow{2}{*}{$\begin{array}{c}\text { New seedling } \\
\text { price wholesale } \\
(E \cup R)\end{array}$} & \multirow[b]{2}{*}{$\mathrm{L}$} & \multirow[b]{2}{*}{$\mathbf{H}$} & \multirow{2}{*}{$\begin{array}{c}\text { B } \\
\text { (EUR) }\end{array}$} & \multirow{2}{*}{$\begin{array}{l}\text { Price } \\
\text { (EUR) }\end{array}$} \\
\hline & & & & & & & & & \\
\hline $\begin{array}{l}\text { Horse } \\
\text { chestnut }\end{array}$ & 58.28 & 97 & 150 & 0.84 & 108.08 & 1.44 & 0.6 & 1058.34 & 772.79 \\
\hline $\begin{array}{l}\text { Northern } \\
\text { red oak }\end{array}$ & 81.21 & 135 & 200 & 0.80 & 52.98 & 1.44 & 0.80 & 785.32 & 732.23 \\
\hline Plane tree & 95.54 & 159 & 300 & 0.97 & 75.23 & 1.44 & 0.76 & 1236.90 & 1320.01 \\
\hline $\begin{array}{l}\text { Large } \\
\text { leaved } \\
\text { linden }\end{array}$ & 50.95 & 84 & 150 & 0.93 & 84.77 & 1.44 & 0.72 & 756.51 & 735.45 \\
\hline Ash & 41.71 & 69 & 150 & 1.00 & 52.98 & 1.44 & 0.68 & 441.83 & 435.50 \\
\hline Ash & 48.72 & 81 & 150 & 0.96 & 52.98 & 1.44 & 0.72 & 502.77 & 502.53 \\
\hline Ash & 52.54 & 87 & 150 & 0.91 & 52.98 & 1.44 & 0.6 & 536.01 & 425.29 \\
\hline Ash & 38.85 & 64 & 150 & 1.00 & 52.98 & 1.44 & 0.6 & 416.90 & 362.58 \\
\hline Maple & 33.43 & 55 & 150 & 1.00 & 52.98 & 1.44 & 0.76 & 369.81 & 407.40 \\
\hline Beech & 63.69 & 106 & 150 & 0.76 & 39.74 & 1.44 & 0.72 & 507.62 & 405.06 \\
\hline Ash & 73.24 & 122 & 150 & 0.61 & 52.98 & 1.44 & 0.76 & 716.07 & 481.30 \\
\hline Ash & 50.95 & 84 & 150 & 0.93 & 52.98 & 1.44 & 0.68 & 522.16 & 479.42 \\
\hline Ash & 46.17 & 76.9 & 150 & 0.99 & 52.98 & 1.44 & 0.76 & 480.61 & 522.48 \\
\hline Ash & 52.22 & 87 & 150 & 0.92 & 52.98 & 1.44 & 0.56 & 533.24 & 396.56 \\
\hline Ash & 60.5 & 100.8 & 150 & 0.81 & 52.98 & 1.44 & 0.72 & 605.26 & 511.37 \\
\hline Spruce & 39.8 & 66.3 & 200 & 1.00 & 7.42 & 1.44 & 0.72 & 172.69 & 180.23 \\
\hline Oak & 74.2 & 123.6 & 200 & 0.87 & 44.50 & 1.44 & 0.68 & 629.53 & 542.12 \\
\hline Ash & 78.98 & 131.6 & 150 & 0.49 & 52.98 & 1.44 & 0.8 & 765.93 & 439.52 \\
\hline Ash & 57.32 & 95.5 & 150 & 0.85 & 52.98 & 1.44 & 0.8 & 577.56 & 570.72 \\
\hline Ash & 58.91 & 98.1 & 150 & 0.83 & 52.98 & 1.44 & 0.88 & 591.41 & 626.98 \\
\hline
\end{tabular}

\section{DISCUSSION AND CONCLUSION}

Constant social changes and an increased pressure on different types of green surfaces are a challenge to the traditional maintenance method. Due to insufficient information about the social needs and the expectations of different user groups, problems related to the maintenance and various conflicts have been occurring during the past couple of decades.
Green urban projects are often designed according to architectural and aesthetic standards which are not directed enough to the local public and its specific needs.

The use of methods for urban tree valuation has been recorded in Croatia. Historically the oldest attempt is the tree pricing method by Marinković [18] and Piškorić [19] which uses equation to calculate the value of an individual tree in the park and other areas based on the 
material value of timber which is then multiplied based on species' significance, condition and importance, as well as on the location of the tree. The most comprehensive research regarding the aesthetic and the recreational value of Croatian coastal forests was carried out in period from 1995 to 2001 [20, 21]. The economic impact of the aesthetical/ambient value of forests in relation to tourism and the local population was estimated only for the coastal part.

In the region, the forestry sector, mostly due to its long tradition, has not fully adapted to the changing of the paradigm of forestry from a "timber-gaining" part of the economy to a service that manages forest in a multifunctional way, providing equally important timber, nonwood products and services to a large number of user groups. This is even more apparent when it comes to urban forests. In the last few decades, the urbanization was growing in the main cities of South East Europe region. In these cities, the density of the population has increased dramatically, which also changed the borders of the cities. This is connected both to the economic growth and to the process of industrialization. The behaviour of urban residents, being a part of the social system, influences urban forests, and, vice versa, the amount and the accessibility of these critical resources shape human behaviour. Knowing the behaviour of urban residents could provide a valuable input to the management and the decision making related to urban forests. The demand for green surfaces with their related social and cultural services will make them more appealing, and increase their number in the future. The applied Danish method is based on the depletion principle, according to which the value of the trees is reduced according to the higher age. The method uses the biological predefined maximal DBH according to the predefined expected tree age, and calculates the economic tree value which has the $\mathrm{DBH}$ smaller than the predefined maximum. The main obstacle in applying this method is that it cannot be successfully used when the tree exceeds the expected age.

When developing or applying a model for plant appraisal, it is important that it could be used by the entire green industry and accepted by the law framework [17, 22]. A variety of approaches have been used to estimate the value of urban trees. Depending on the objective of the valuation, the existing tree valuation methods can be divided into four groups [23]. Indirect methods such as the Contingent Valuation Method (CVM), the Hedonic Price Method (HPM) and the Travel Cost Method (TCM) are most widely used for valuation of all green areas [24]. These methods are not considered to be the official valuation methods for urban trees [25]. Among direct methods, the formula method like the Danish one [17] is an appropriate method for the individual tree assessment [23].

The social development and the increasing number of urban forest users will also increase the need to determine the economic value of the urban green infrastructure and trees. Since a unique evaluation method does not exist, future benefits and values of the urban forests will change depending on the need and the trends of the people who use them, and they should be included in calculation.

\section{REFERENCES}

1. OSTOIĆ KRAJTER S, POSAVEC S, VULETIĆ D, STEVANOV M 2013 Valuation of urban forest benefits: a literature review (in Croatian with English summary). Works (Croatian Forest Research Institute) 45 (2):161-173
2. LOVRIĆ M 2009 The Value of Urban Forests in Residential Land Use. An exploratory study of the influence of urban forests on the price of housing real estates in Zagreb, Croatia. MSc thesis, University of Sarajevo, Faculty of Forestry, Sarajevo, BiH, $66 \mathrm{p}$ 
3. POUTA E, SIEVÄNEN T 2001 Luonnon virkistyskäytön kysyntätutkimuksen tulokset Kuinka suomalaiset ulkoilevat? In: Sievänen T (ed) Luonnon virkistyskäyttö 2000. Finnish Forest Research Institute, Helsinki, Finland, pp 32-196

4. KONIJNENDIJK C, NILSSON K, RANDRUP TB, SCHIPPERIJNJ 2005 Urban Forests and Trees. Springer, Berlin, Germany, 520 p

5. TYRVÄINEN L, VÄÄNÄNEN H 1998 The economic value of urban forest amenities: an application of the contingent valuation method. Landscape Urban Plan 43 (1):105-118. DOI: http://dx.doi. org/10.1016/S0169-2046(98)00103-0

6. TYRVÄINEN L, SILVENNOINEN H, KOLEHMAINEN O 2003 Ecological and aesthetic values in urban forest management. Urban For Urban Gree 1 (3): 135-149. DOI: http://dx.doi.org/10.1078/1618$\underline{8667-00014}$

7. TYRVÄINEN L 2001 Economicvaluation of urban forest benefits in Finland. J Environ Manage 62 (1):75-92. DOI: http://dx.doi.org/10.1006/ jema.2001.0421

8. ULRICH RS, SIMONS RF, LOSITO BD, FIORITO E, MILES MA, ZELSON M 1991 Stress recovery during exposureto natural and urban environments. J Environ Psychol 11 (3): 201-230. DOI: http:// dx.doi.org/10.1016/S0272-4944(05)80184-7

9. KWEON BS, SULLIVAN WC, WILEY AR 1998 Green common spaces and the social integration of inner-cityolder adults. Environ Behav 30 (6): 832-858. DOI: http://dx.doi. org/10.1177/001391659803000605

10. TYRVÄINEN L 1999 Monetary valuation of urban forest amenities in Finland. Finnish Forest Research Institute, Vantaa, Finland, $129 \mathrm{p}$

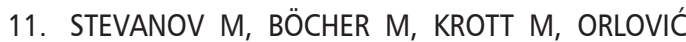
S, VULETIĆ D, OSTOIĆ KRAJTER S 2011 Analytic model of departamental research as sciencebased advising of actors in political process. Analysis of research activity of the Institute of Lowland Forestry and Environment from Novi Sad (in Croatian with English summary). Sumar List 135 (9-10): 449-465

12. ARBUTINA D 1996 The Development of Ribnjak Garden in Kaptol, Zagreb, and Designs for the Park. Prostor 4 (2): 253-270
13. MCPHERSON EG 1994 Energy-saving potential of trees in Chicago. In: McPherson EG, Nowak $\mathrm{DL}$, Rowntree RA (eds) Chicago's urban forest ecosystem: results of the Chicago Urban Forest Climate Project. USDA Forest Service General Technical Report NE-186. Radnor, Pennsylvania, USA, pp 95-114. URL: http://www.nrs.fs.fed.us/ pubs/gtr/gtr ne186.pdf (21 October 2014)

14. MCPHERSON EG 2007 Benefit-Based Tree Valuation. Arboriculture \& Urban Forestry 33 (1): 1-11

15. NOWAK DJ, CRANE DE, STEVENS JC, IBARRA M 2002 Brooklyn's urban forest. United States Department of Agriculture, Forest Service, Northeastern Forest Experiment Station, General Technical Report NE-290 Radnor,Pennsylvania, USA, 107 p. URL: http://www.fs.fed.us/ne/ newtown square/publications/technical reports/ pdfs/2002/gtrne290.pdf (18 October 2014)

16. STRAKA TJ, PETERSON KS 2012 Economic Components of Urban Tree Value. In: Southern Regional Extension Forestry, A Regional Peer Reviewed Technology Bulletin, 19 p. URL: http:// www.sref.info/resources/publications/economiccomponents-of-urban-tree-value/at download/ file (11 August 2014)

17. RANDRUP TB, PAULSEN L, HOLGERSEN S 2003 VAT 03 - Vćrdisćtning af trćer I byrum, have, park oglandskab [Monetary valuation of trees in urban space, garden, park and landscape] (in Danish). Forlaget GrřntMiljř, Frederiksberg, Denmark

18. MARINKOVIĆ B 1975 Procjena vrijednosti ukrasnog i drugoga drveća i grmlja prilikom ekspropriracije (in Croatian). Hortikultura 3: 87-88

19. PIŠKORIĆ O 1975 Procjena vrijednosti na parkovnim i drugim površinama (in Croatian). Hortikultura 1: 32-33

20. HORAK S, MARUŠIĆ Z, WEBER S 2001 The aestetic and recreational value of Croatian coastal forests to the local population. In: Final report of Coastal forest reconstruction and protection project in Croatia. Institute of Tourism, Zagreb, Croatia

21. KNEŽEVIĆ S 1992 Povijest Potoka i memorija Tkalčićeve izložbe "Vrtne arhitektice za Tkalčićevu ulicu" (in Croatian). Galerija ULUPUG, Zagreb, Croatia 
22. LOVRIĆ M 2009 The value of urban forests in residential land use. An exploratory study of the influence of urban forests on the price of housing real estates in Zagreb, Croatia. MSc thesis, University of Sarajevo, Faculty of Forestry, Sarajevo, Bosnia and Herzegovina, $66 \mathrm{p}$

23. JIM CY 2006 Formulaic expert method to integrate evaluation and valuation of heritage trees in compact city. Environ Monitor Assess 116 (1-3): 53-80. DOI: http://dx.doi.org/10.1007/s10661$\underline{006-7245-x}$
24. TYRVÄINEN L, PAULEIT S, SEELAND K, DE VRIES S 2005 Benefits and Uses of Urban Forests and Trees. In: Konijnendijk CC, Nilsson K, Randrup TB, Schipperijn J (eds) Urban Forests and Trees. Springer-Verlag, Berlin, Heidelberg, Germany, pp 81-114. DOI: http://dx.doi.org/10.1007/3-54027684-X 5

25. GRANDE-ORTIZ MA, AYUGA-TÉLLEZ E, CONTATOCAROL ML 2012 Methods of Tree Appraisals. Arboriculture \& Urban Forestry 38 (4): 130-140

(C) 2015 by the Croatian Forest Research Institute. This is an Open Access paper distributed under the terms of the Creative Commons Attribution License (http://creativecommons.org/licenses/by/4.0). 